\title{
Tetracycline levels in bronchial secretions
}

M. J. CAMPBELL

From the Department of Bacteriology, Wright-Fleming Institute, St. Mary's Hospital Medical School, London

SYNOPSIS The excretion of tetracycline $\mathrm{HCl}$ in sputum was studied in 42 hospital patients

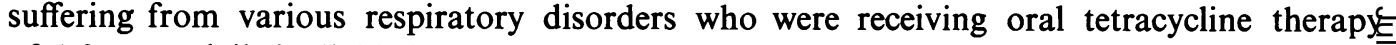
of 1.0 gram daily in divided doses.

The tetracycline levels were estimated biologically by a cup-plate agar diffusion method $\overrightarrow{0}$ using $B$. cereus. Two separate methods of sputum homogenization are described: enzymic liquefaction with pronase, a powerful proteolytic enzyme, and ultracentrifugation at 103,000 for three hours which sediments the viscous mucoids leaving $80-90 \%$ as a clear, non-viscous supernatant. The two methods allowed duplicate assays on sputum samples and generall $\mathrm{S}^{\circ}$ showed close agreement. The ultracentrifugation technique is favoured for normal purpose $\mathbb{Q}$ because of its simplicity and the avoidance of any biochemical interference.

A close correlation was shown between the tetracycline levels in sputum samples and the average serum level for each patient. Over the serum tetracycline range $1 \cdot 0-5.0 \mu \mathrm{g} / \mathrm{ml}$, the mean sputum tetracycline levels after centrifugation were $23-18 \%$, and the average level was. $0.50 \mu \mathrm{g} / \mathrm{ml}$.

The levels found in sputum were compared with the minimum inhibitory concentratio of tetracycline for strains of $H$. influenzae and Strep. pneumoniae. Eighty-six percent of $2 \dot{8}$ $H$. influenzae strains tested and all Strep. pneumoniae strains tested were sensitive to $0.5 \mu \mathrm{g} / \mathrm{m}$ tetracycline. The remaining $H$.influenzae strains had a minimum inhibitory concentration of $1 . \otimes$ $\mu \mathrm{g} / \mathrm{ml}$ or higher, a tetracycline level in sputum which appeared to be outside the mean range at the oral dosage of 1.0 gram daily.

Hence it is suggested that a small proportion of patients with lower respiratory tract in $\tilde{N}$ fections due to $H$. influenzae would be unresponsive, or only partially responsive, to this usuals therapeutic range of tetracycline.

Bacterial infection is believed to be an important factor in influencing the prognosis of patients with chronic bronchitis (Reid, 1954; Fletcher, 1959 and 1965), and although its exact role in the acute episodes which characterize the clinical picture of the disease is not clear (Davis, Grobow, Tompsett, and McClement, 1961), antibacterial agents have been widely advocated and employed in treatment.

It is generally held that Haemophilus inReceived for publication 11 September 1969. fluenzae and, less certainly, Streptococcus pneu? moniae, are the most important bacteriat pathogens in bronchitis (Mulder, 1938; Mulde Goslings, van der Plas, and Lopes Cardoze 1952; May, 1953). As these organisms ar sensitive in vitro to drugs of the tetracycline series, these antibiotics have been widely used in the treatment of chronic bronchitis. Mang clinical and bacteriological studies of theris peutic trials with tetracyclines have been re ported with varied results, and, although the 
higher dose schedules have been most effective, complete elimination of $H$. influenzae from sputum has never been reported. There is no evidence to suggest that the persistent organisms are more resistant to tetracyclines and their survival may be due to failure to attain therapeutically adequate levels of tetracycline in the respiratory tract. Bronchial infections are essentially inflammations of the mucosal surface with little invasion of the tissues by the organisms (Hers and Mulder, 1953). The elimination of respiratory pathogens may, therefore, rely on the level of the antibiotic drug within the bronchial secretions.

The purpose of this work was to measure the tetracycline excretion in the bronchial secretions of patients receiving tetracycline orally in normal therapeutic dosage, and to relate these levels to the minimum inhibitory concentration (MIC) of tetracycline for strains of $\boldsymbol{H}$. influenzae and Strep. pneumoniae. Preliminary studies were directed at finding a simple but satisfactory method of homogenization of sputum, which would allow accurate measurement of biologically active compounds.

\section{Materials and Methods}

\section{PATIENTS}

Forty-two hospital patients, suffering from various acute and chronic respiratory disorders and producing significant amounts of sputum, were studied. Each received $1.0 \mathrm{~g}$ tetracycline $\mathrm{HCl}$ daily in four divided doses. In some cases a loading dose of $2.0 \mathrm{~g}$ was given during the first 24 hours. Other drugs were given when necessary but the only other antibacterial agents were sulphonamides, which were administered to a few patients. The bacteriostatic effects of sulphonamides were neutralized in the assay procedure.

The patients were instructed to swallow the capsules whole rather than to chew them and to expectorate sputum from the chest with as little salivary contamination as possible. The sputum was collected over 24- or 48-hour periods, depending on the volume, in $250 \mathrm{ml} \mathrm{screw-capped}$ jars, and the samples were stored at $4^{\circ} \mathrm{C}$ for a maximum of 10 days before the assay. Venous blood samples were obtained from each patient on two or more separate days, and approximately three hours after a preceding tetracycline capsule. The serum was separated immediately and stored at $-10^{\circ} \mathrm{C}$ until the assay.

TETRACY CLINE

Tetracycline hydrochloride in $250 \mathrm{mg}$ capsules were used for administration to the patients.
Microcrystalline tetracycline hydrochloride ${ }^{1} \propto$ (Achromycin Lederle) was used in the prepara- $\overline{\frac{\sigma}{5}}$ tion of standard solutions for the bio-assays.

ENZYMES

The following enzyme preparations were used: pancreatin (BDH), trypsin (Worthington Bio-O chemical Corp., Freehold, N.J.), and Pronase-Po (Kaken Chemical Company, Tokyo).

MEDI A

Difco Penassay agar was used in the tetracycline bio-assay. A fluid medium containing co-enzyme $\vec{\omega}$ I (DPN) and haematin (Holt, 1962) was used for determining the antibiotic sensitivity (MIC)용 of the $H$. influenzae strains. For estimating the $\mathrm{cj}_{\mathrm{N}}^{\mathrm{N}}$ MIC of Strep. pneumoniae strains, a fluid mediumir with the following final composition was used:

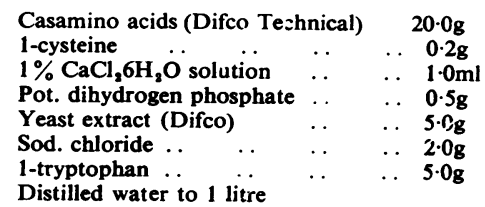

The $\mathbf{p H}$ was corrected to $7 \cdot 8$, and the medium autoclaved for 15 to $20 \mathrm{~min}$ at $10 \mathrm{lb} / \mathrm{sq}$ inch. After autoclaving, sterile $50 \%$ glucose solution was added to give a final concentration of $0.5 \%$.

BACTERIAL STRAINS

Twenty strains of $H$. influenzae $e^{2}$ and two strains of $\boldsymbol{H}$. parainfluenzae were freshly isolated from sputum on heated blood agar. The identification 횽 of these organisms was confirmed by their: requirements for haematin and coenzyme $I$. 3 The organisms were subcultured and main- $\delta$ tained in a fluid medium (Holt, 1962). Nine stock strains of $H$. influenzae (NCTC 4560, 4842, 응 $8143,8465,8468,8469,8470,8472$, and 8473), and two stock strains of $H$. parainfluenzae (NCTC 4101 and 7857) were similarly tested and maintained in this medium.

Eleven strains of Strep. pneumoniae were iso- N lated from sputum. These were identified by their $N$ typical colonial appearance, the production of $\sigma$ greening on blood agar plates, sensitivity to Optochin, and bile solubility. They were subcultured and maintained in the synthetic broth $\stackrel{\infty}{\rho}$ described above.

HOMOGENIZATION OF SPUTUM
As tetracyclines are acid- and alkali-labile compounds (McCormick, Fox, Smith, Bitler,

${ }^{1}$ Kindly donated by Cyanamid of Great Britain Ltd.

${ }^{2}$ Eight strains were obtained through the courtesy of Professor B. Lacey. 


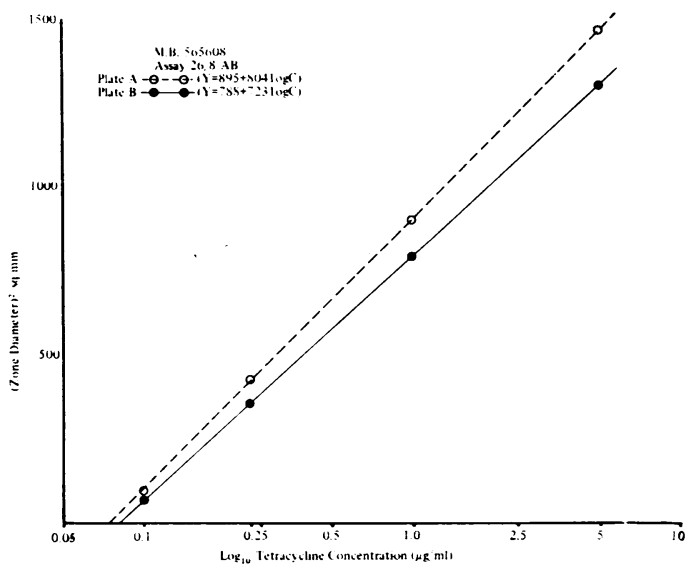

Fig. 1 Tetracycline concentration of four standard solutions.

Reichenthal, Origoni, Muller, Winterbottom, and Doerschuk, 1957), care must be taken during homogenization of sputum to preserve antibiotic activity. Proteolysis with several enzyme preparations, including $2 \%$ pancreatin (Rawlins, 1953), trypsin, and chymotrypsin, all gave unsatisfactory or variable results but consistently good homogenization was obtained with Pronase-P, an enzyme isolated from Streptomyces griseus. This enzyme has maximum proteolytic activity at $p \mathrm{H} 8.0$ and an optimum temperature range of 40 to $60^{\circ} \mathrm{C}$; calcium ions are essential for optimum activity (Nomoto and Narahashi, 1959).

Pronase was freshly prepared as a $10 \mathrm{mg} / \mathrm{ml}$ solution in tris-(hydroxy-methyl)-aminomethane (Tris)/ $\mathrm{HCl}$ buffer, $p \mathrm{H} 8 \cdot 1$, at $37^{\circ} \mathrm{C}$ (Gomori, 1946 ), containing in addition $0.005 \mathrm{M}$ calcium chloride. Approximately $10 \mathrm{~g}$ aliquots of sputum were weighed into capped test tubes and $10 \%$ $\mathrm{w} / \mathrm{v} \mathrm{Tris} / \mathrm{HCl}$ buffer was added. Pronase solution was then added to give a final concentration of $0.1 \mathrm{mg}$ pronase $/ \mathrm{g}$ sputum. The tubes were incubated at $42^{\circ} \mathrm{C}$ in a water bath for up to one and a half hours, until liquefaction was complete. These digests were then used directly in the bio-assay.

SEPARATION OF PHASES OF SPUTUM GEL In chemical and structural studies on bovine cervical mucus, Gibbons (1959) found that centrifugation at $103,000 \mathrm{~g}$ for up to five hours separated the macromolecular glycoproteins forming the discontinuous phase of the gel from the continuous phase which forms a non-viscous supernatant solution. This method was found to be applicable to sputum.

Sputum samples were centrifuged at $103,000 \mathrm{~g}$ for three hours under continuous refrigeration. Non-viscous supernatants comprising $80-90 \%$ $\mathrm{w} / \mathrm{w}$ of the original sputum specimens were separated, and these were stored at $-10^{\circ} \mathrm{C}$ until they were assayed. In some experiments the discontinuous phase functions were homogenized with pronase, using an enzyme concentration of $2 \mathrm{mg} / \mathrm{g}$ sputum and an incubation period of three hours.

\section{ASSAY OF TETRACYCLINE}

The tetracycline concentration in both serurn and sputum samples was measured biologicallyo by an agar diffusion method using the punch" hole technique and with Bacillus cereus ( $\mathrm{NCIB}^{\circ}$ 8012; ATCC 9634) as test organism (modified $\vec{\omega}$ from Grove and Randall, 1955). Large assayo plates $(30 \times 30 \mathrm{~cm})$ were prepared with a base layer of $75 \mathrm{ml}$ phosphate-buffered Difco Penassayh agar ( $p$ H 5.6), and a top seeded layer, comprising $50 \mathrm{ml}$ of the same agar, in which had beenis incorporated $2.9 \times 10^{4} / \mathrm{ml} B$. cereus spores. N Seven-millimetre diameter wells were cut to ang assay design template. The standard tetracyclinesolutions were prepared from micro-crystalline tetracycline $\mathrm{HCl}$ with $0.01 \mathrm{~N} \mathrm{HCl}$ to $1 \mathrm{mg} / \mathrm{mK}$ concentration, and then diluted with sterile distilled water to $10 \mu \mathrm{g} / \mathrm{ml}$ concentration Aqueous dilutions of $5 \cdot 0,1 \cdot 0,0 \cdot 25$, and $0 \cdot 1 \mu \mathrm{g} / \mathrm{mb}$ TC concentration were used as standard soluo tions in the assay. In some assays $10 \mathrm{mg} / 100 \mathrm{~mm}$ potassium para-aminobenzoate was added t\& the agar to neutralize the bacteriostatic effec of sulphonamides.

An $8 \times 8$ quasi-latin square design was use $\overrightarrow{\vec{\Phi}}$ incorporating 12 separate test samples, and standard tetraciycline solutions at four levels of concentration. This allowed four estimations at each level. Three standard drops $(0.06 \mathrm{ml})$ of eact test sample were added to the appropriate well and the plate was allowed to stand at roon temperature for one hour before incubatio at $30^{\circ} \mathrm{C}$ for 16 to 20 hours.

The diameters of the inhibition zones around the wells were measured in two directions at $90^{\circ}$ to each other and an average was recordeco Standard curves were constructed for each plat on semi-log paper. The concentration of each of the four standard solutions was plotted on the $\log _{10}$ scale against the square of the meat diameter of the inhibition zones (Fig. 1). The concentrations in the unknown samples were then read off from these curves. Thus tetracyclin levels were measured directly in the test solution without attempting to allow for the variable protein concentration. A $10 \%$ correction factoo was allowed for the dilution of the pronase? digested samples by the Tris/ $\mathrm{HCl}$ buffer. Sterilizag tion of sputum samples before bioassay was found to be unnecessary.

The lowest concentration of tetracycline consistently giving an observable inhibition zone around the wells was $0.09 \mu \mathrm{g} / \mathrm{ml}$. Pronase digests of antibiotic-free sputum samples showed 


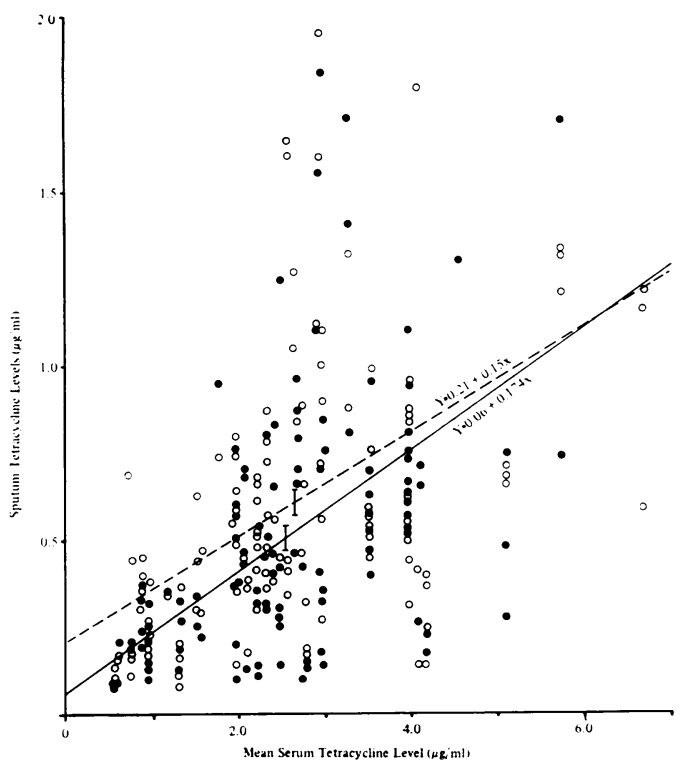

Fig. 2 Tetracycline levels in sputum compared with mean levels in serum from 42 patients.

\begin{tabular}{|c|c|c|c|c|}
\hline \multirow{3}{*}{$\begin{array}{l}\text { Serum TC } \\
(\mu g / m l)\end{array}$} & \multicolumn{4}{|c|}{ Pre-assay Treatment Methods } \\
\hline & \multicolumn{2}{|c|}{$\begin{array}{l}\text { Ultracentrifugation } \\
(y=0.06+0 \cdot 17 x)\end{array}$} & \multicolumn{2}{|c|}{$\begin{array}{l}\text { Pronase Digestion } \\
(y=0 \cdot 21+0 \cdot 15 x)\end{array}$} \\
\hline & $\begin{array}{l}\text { Sputum } T C \\
(\mu g / m l)\end{array}$ & $\%$ Serum Level & $\begin{array}{l}\text { Sputum } T C \\
(\mu g / m l)\end{array}$ & $\%$ Serum Level \\
\hline 1.0 & $\begin{array}{l}0.23 \\
(0.13-0.33)^{1}\end{array}$ & 23 & 0.36 & 36 \\
\hline $2 \cdot 5$ & $\begin{array}{l}0.50 \\
(0.44-0.56)\end{array}$ & $\begin{array}{l}20 \\
(18-22)\end{array}$ & $\begin{array}{l}0.20-0.40) \\
0.59 \\
(0.53-0.65)\end{array}$ & $\begin{array}{l}(20-40) \\
23 \\
(21-26)\end{array}$ \\
\hline $5 \cdot 0$ & $\begin{array}{l}0.93 \\
(0.79-1.07)\end{array}$ & $\begin{array}{l}19 \\
(16-21)\end{array}$ & $\begin{array}{l}0.96 \\
(0 \cdot 82-1 \cdot 1)\end{array}$ & $\begin{array}{l}19 \\
(16-22)\end{array}$ \\
\hline $7 \cdot 5$ & $\begin{array}{l}1 \cdot 36 \\
(1 \cdot 10-1 \cdot 62)\end{array}$ & $\begin{array}{l}18 \\
(15-22)\end{array}$ & $\begin{array}{l}1 \cdot 34 \\
(1 \cdot 08-1 \cdot 60)\end{array}$ & $\begin{array}{l}18 \\
(14-21)\end{array}$ \\
\hline
\end{tabular}

Table Calculated values of tetracycline (TC) concentrations in sputum at particular TC levels in serum

$195 \%$ iimits in brackets.

an inhibition zone equivalent to a tetracycline level of not greater than $0.13 \mu \mathrm{g} / \mathrm{ml}$. This activity was shown not to be a property of the pronase of Tris/ $\mathrm{HCl}$ buffer but appeared to be a property or the proteolytic digest of sputum. The biological activity of tetracycline in $\mathrm{Tris} / \mathrm{HCl}$ buffer between $p \mathrm{H} \mathrm{5.0}$ and 8.75 was found to be substantially unchanged even after three days. The addition of pronase to an aqueous tetracycline solution in concentrations up to $100 \mathrm{mg} \%$ at $42^{\circ} \mathrm{C}$ for two hours also had no effect on the biological activity.
ESTIMATIONS OF MINIMUM INHIBITORY CONCENTRATION OF TETRACYCLINE

Haemophilus influenzae

The minimum inhibitory concentration (MIC) 흘 of tetracycline for strains of $\boldsymbol{H}$. influenzae was $\vec{F}$ measured in a fluid medium incorporating two- $\stackrel{\rho}{\rightarrow}$ fold dilutions of standard tetracycline, beginning? at $8 \mu \mathrm{g} / \mathrm{ml}$ concentration. Of an overnight culture $0.02 \mathrm{ml}$ was added and the tubes were incubated aerobically for 16 to 20 hours at $\varnothing$ $37^{\circ} \mathrm{C}$. The turbidity due to growth was subsequently recorded. The end point was further defined by counting the viable organisms in the tubes about the end point. A hundredfold $\vec{\omega}$ reduction in the count, compared with controls, was taken as evidence of inhibition of growth by용 tetracycline.

\section{Streptococcus pneumoniae} $(1: 1)$ to two-fold serial dilutions of tetracycline? solutions in a series of screw-capped bijoubottles, beginning with a concentration of $\_$ $8 \mu \mathrm{g} / \mathrm{ml}$. Of an overnight culture, $0.02 \mathrm{ml}$ was then added and the tubes were incubated ate $37^{\circ} \mathrm{C}$ for 24 hours. Turbidity due to growth was $O$ subsequently recorded. A sharp end point was obtained.

\section{Results}

OVERALL VARIATION IN TETRACYCLINE

\section{LEVELS IN SPUTUM}

The tetracycline levels in the sputum and serumo samples of all 42 patients studied are shown' graphically in Figure 2 . The daily sputum levels have been plotted against the average serumô tetracycline level for each patient. The assay values in sputum samples treated by pronase digestion and ultracentrifugation are plotted $>$ separately and regression curves constructed을. for each method. Tetracycline was detected $N$ in all sputum samples obtained during oral therapy but the levels were low during the ${ }^{N}$ initial 24-hour collection period and often only $N$ reached a peak after 48 hours, so the results from samples taken in the first 24-hour periode have been excluded from the statistical analysis.

The results show a fairly wide scatter about $a \stackrel{\text { ? }}{?}$ broad mean, but the regression lines show a very 0 close agreement between the tetracycline levels

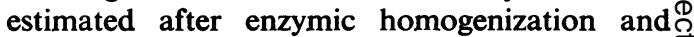
those after ultracentrifugation. The average $\mathbb{\Omega}_{\mathbb{Q}}$ serum tetracycline level in 76 estimations was 0 $2.68 \mu \mathrm{g} / \mathrm{ml}$, with the majority of values falling in the range of $1 \cdot 0-4 \cdot 0 \mu \mathrm{g} / \mathrm{ml}$. The average sputum tetracycline levels were $0.50 \mu \mathrm{g} / \mathrm{ml}$. after ultracentrifugation and $0.61 \mu \mathrm{g} / \mathrm{ml}$ after

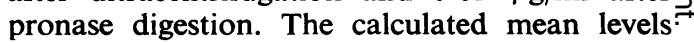




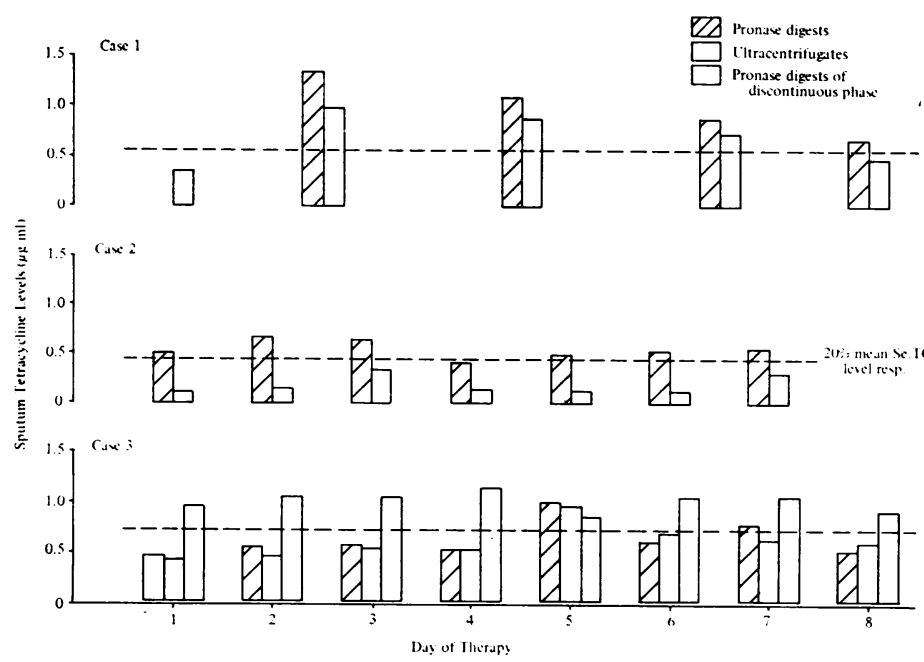

Fig. 3 Variation in sputum tetracycline levels.

at serum tetracycline values are shown in the Table. The levels were higher in the pronase treatment samples at the lower serum levels, but almost identical with those obtained after ultracentrifugation in the higher serum range. Over the range $1.0-5.0 \mu \mathrm{g} / \mathrm{ml}$ in serum, the mean sputum levels were 0.23 to $0.93 \mu \mathrm{g} / \mathrm{ml}$ after ultracentrifugation, and 0.36-0.96 $\mu \mathrm{g} / \mathrm{ml}$ after pronase digestion. These sputum tetracycline concentration ranges are $23-18 \%$ and $36-19 \%$ of the serum levels respectively.

\section{VARIATION IN SPUTUM TETRACYCLINE LEVELS IN INDIVIDUAL PATIENTS}

Although good agreement was obtained overall the variation in the sputum levels of tetracycline was found to be considerable even amongst samples from a single patient. This variation is illustrated in the following clinical examples. The results are shown in Figure 3.

\section{Case 1}

W.B., a man aged 50 years, was admitted to hospital following a road traffic accident with a fractured shaft of the right femur. He had a past history of a longstanding chronic productive cough and of recurrent winter bronchitis. The studies were performed during an acute episode of bronchitis. There was no evidence of any other disease. Blood samples were obtained on days 5 and 8 of treatment with tetracycline and the serum tetracycline levels were estimated as 2.75 and $2.6 \mu \mathrm{g} / \mathrm{ml}$ respectively.

\section{Case 2}

The patient, M.B., was a woman aged 30 years, who had suffered from severe bronchiectasis for several years. During this study she produceकु $15-45 \mathrm{ml}$ of very tenacious purulent sputum daily Cultural studies on the first sputum specimeno demonstrated a pure growth of $H$. influenza $\frac{\vec{\nu}}{\vec{T}}$ This organism was not isolated at the end of the study but the culture plates were overgrow: with a Proteus species. The serum tetracycline levels on days 3 and 6 were $1.9 \mu \mathrm{g} / \mathrm{ml}$ and 2.8 $\mu \mathrm{g} / \mathrm{ml}$ respectively (average of $2 \cdot 25 \mu \mathrm{g} / \mathrm{ml}$ ).

\section{Case 3}

A 70-year-old man, F.M., an inpatient with कै fractured shaft of the femur, had an acute exacerbation of chronic bronchitis while in hospital and was placed on oral tetracycline $250 \mathrm{mg}$ four times daily. He produced moderate? volumes of mucoid sputum daily. Serum tetrae cycline levels on days 4 and 7 were 3.8 and $3 . j$ $\mu \mathrm{g} / \mathrm{ml}$ respectively, an average of $3.55 \mu \mathrm{g} / \mathrm{ml}$. $\quad$ ir

The maximum tetracycline levels in sputunit were obtained in these examples by the second day, and thereafter remained fairly constant throughout the course of the study. The levels in samples after pronase digestion were usually higher than after ultracentrifugation, and markedly so in case 2 . The tetracycline levels found ifo each patient correspond more closely wher compared as percentage values of the respective average serum tetracycline levels.

In case 2 the tetracycline levels after pronas digestion, at 18 to $29 \%$ of the average serunt level, were of the usual order found in sputun 8 but the values in supernatant samples afte ultracentrifugation, at 5 to $14 \%$, were unusuallis low. These low levels presumably indicate that a high proportion of the tetracycline was sedie mented with the discontinuous phase and possibly was protein-bound. The sputum from this patient was unusually viscid and the supernatang portion was only approximately $50 \%$ compared with the usual $80-90 \%$.

The tetracycline concentration was estimated i录 the discontinuous phase of sputum samples ifo case 3. Assay after pronase digestion of the geb residue from ultracentrifugation gave a range. of 0.86 to $1.14 \mu \mathrm{g} / \mathrm{g}$, or 24 to $32 \%$ of the averageু serum level. These levels are consistently higher than the whole sputum measurements and sugges differential binding by the sedimented proteirw fraction. On the assumption that pronase release the protein-bound tetracycline it was calculate for day 3 that $21 \%$ of the total tetracycline was sedimented in that sample. The removal of such a proportion of the tetracycline is seen to alter the level only slightly as assessed by assa? after the use of the two different treatmen? methods.

MIN I MUM INHIBITORY CONCENTRATION OF TETRACYCLINE

The MIC of tetracycline for 20 freshly isolated strains and 9 NCTC strains of $H$. influenzae 


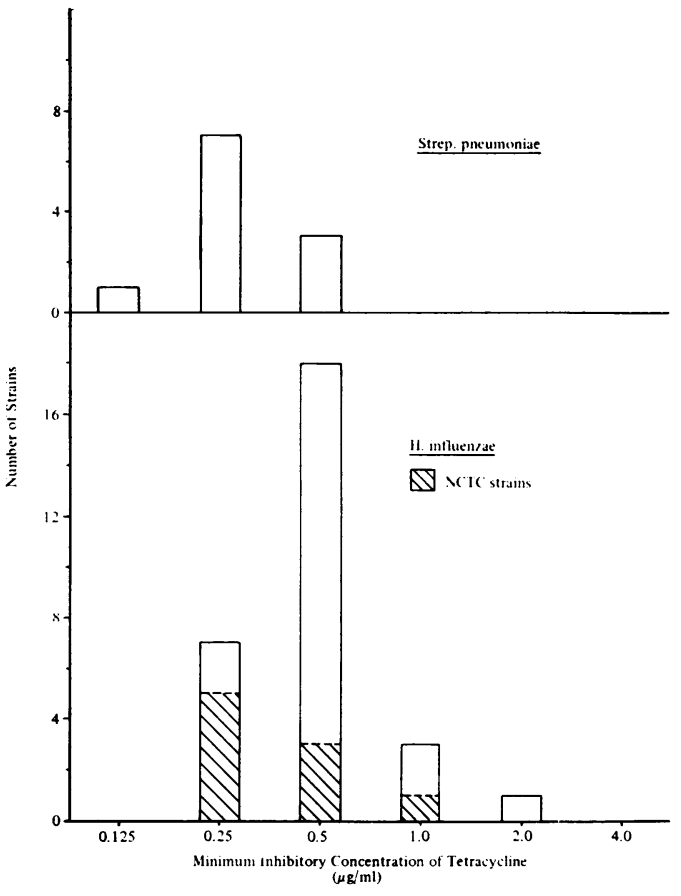

Fig. 4 Minimum inhibitory concentration of tetracycline from 11 strains of Strep. pneumoniae.

are shown in Figure 4. Seven strains were sensitive to $0.25 \mu \mathrm{g} / \mathrm{ml}$ or less and 18 to between 0.25 and $0.5 \mu \mathrm{g} / \mathrm{ml}$. Thus $86 \%$ of all the strains were sensitive to $0.5 \mu \mathrm{g} / \mathrm{ml}$. The MIC for three strains was $1.0 \mu \mathrm{g} / \mathrm{ml}$ and for one strain $2.0 \mu \mathrm{g} / \mathrm{ml}$.

The results from 11 freshly isolated strains of Strep. pneumoniae are also shown in Figure 4. One strain was sensitive to $0.125 \mu \mathrm{g} / \mathrm{ml}$ or less, seven to 0.25 , and three to $0.5 \mu \mathrm{g} / \mathrm{ml}$ tetracycline or less.

\section{Discussion}

Sputum consists of bronchial secretions variably contaminated with saliva and breakdown products of bacteria and leucocytes, including nucleoprotein. Bronchial secretions are believed to consist of a plasma exudate together with specific mucoproteins and mucopolysaccharides secreted by the bronchial glands. Albumin and other serum protein fractions have been identified in sputum but the proportions have varied in relation to the underlying disease (Brogan, 1960; Biserte, Havez, Voisin, Delahousse, Cuvelier, and Gernez-Rieux, 1961; Atassi, Barker, and Stacey, 1962; Gernez-Rieux, Biserte, Voisin, Havez, and Cuvelier, 1963).
It has been shown in normal human volunteers ${ }_{\Omega}^{c}$ that with an oral dose of $250 \mathrm{mg}$ four times daily, tetracycline $\mathrm{HCl}$ is non-cumulative, and pro- 0 duces a steady serum level at between 2.0 and $\stackrel{0}{=}$ $3.0 \mu \mathrm{g} / \mathrm{ml}$ (Lichter and Sobel, 1962; Putnam, Hendricks, and Welch, 1953 and 1954). Several estimates of the degree of protein-binding of? tetracycline in the blood have been made buto the results have varied widely. However, Wozniak $\frac{\overline{0}}{\overline{0}}$ (1960), in careful dialysis studies using radio- $\frac{5}{-}$ labelled $\mathbf{H}_{3}$ tetracycline, estimated the protein- $\Omega$ bound fraction to be $32 \pm 4 \%$ in human plasma This binding is believed to be readily reversibleand not specifically with any particular protein fraction (Schach von Wittenau and Yeary, 1963) $\vec{\omega}$ However, albumin probably contributes verye largely to the protein-bound fraction, becauses of the large preponderance of this molecule i In studies using radio-labelled tetracyclines;or Eisner and Wulf (1963) reported little differences between the tetracycline levels in serum as $\mathrm{V}$ measured biologically and radiometrically. This suggests that the protein-bound tetracyclineremains biologically active, possibly because of ready dissociation.

Kraus, Casey, and Johnson (1951) measurede the salivary and plasma levels concurrently of both chlortetracycline and oxytetracycline and concluded that the plasma levels were four tos 10 times those in the unstimulated saliva. Mayn ard, Andriola, and Prigot (1953-54) showed that in two patients receiving $1 \mathrm{~g}$ tetracycline daily the salivary levels were 0.22 and $0.84 \mu \mathrm{g} / \mathrm{m}$ respectively. Since tetracycline is excreted in saliva and because there are no means yet available of estimating the degree of salivary contamination in sputum, it would have been. preferable in this study to estimate tetracycline in uncontaminated bronchial secretions. How ever, these are rarely obtainable in any quantity and necessitate minor operative procedures.

The excretion of penicillin (May, 1955; Hafez, Stewart, and Burnet, 1965) and ampicillin (Mas and Delves, 1964 and 1965) in sputum has been extensively studied but little work has been. reported on tetracyclines (May, 1964; Saggers and Lawson, 1968). Saggers and Lawson (1968-9 found no direct correlation between the serunes and sputum levels in 12 children with extensive lung damage due to cystic fibrosis but the meat sputum level was $0.8 \mu \mathrm{g} / \mathrm{ml}$ tetracycline ao $25 \%$ of the serum level. The sputum levels foun $\bar{\sigma}$ in this study also ranged widely but have been ${ }^{4}$ found to correlate with the average serump tetracycline level obtained in each patient? Over the serum tetracycline range $1 \cdot 0-5 \cdot 0 \mu \mathrm{g} / \mathrm{m}$ the mean sputum levels were estimated as $23 \mathrm{t} \&$ $18 \%$ of the serum level in ultracentrifugation samples, and 36 to $19 \%$ in samples treated by pronase digestion. These levels do not appear to differ substantially from those reported for. saliva (Kraus et al, 1951; Maynard et al, 1953 54). 
The two methods of homogenization of sputum described here were both found to be useful, and close agreement was found in the duplicate tetracycline assays. Despite the fact that up to $25 \%$ tetracycline may be sedimented by the ultracentrifugation technique, the level in the non-viscous supernatant was not appreciably lowered. For most purposes this technique would appear to be preferable in any study of biological activity in sputum because of its ease of operation and the avoidance of temperature and $p \mathrm{H}$ changes necessitated by the pronase proteolytic method. The substantially higher values found in the pronase-treated samples at the lower range of tetracycline concentration in sputum were probably due to the observed non-specific biological activity of the proteolytic digest.

Gibbons (1959 and 1961), in his studies on bovine cervical mucus, showed that the nonviscous supernatant resulting from ultracentrifugation contained small quantities of protein identical with serum proteins. As the high molecular weight mucopolysaccharides and mucoproteins are readily sedimented, the ultracentrifuged supernatant of sputum in this study, comprising $80-90 \%$ whole sputum, may be regarded as a plasma exudate variably contaminated with saliva. The serum protein content is small, but, even discounting this factor, the sputum supernatant tetracycline levels are well below the estimated non-protein-bound serum tetracycline levels, ie. $64-72 \%$ total serum tetracycline levels using Wozniak's (1960) findings. Similarly the whole tetracycline levels, as measured after pronase digestion, are also low, but correspond to values found by Saggers and Lawson (1968). There are several possible explanations for these relatively low tetracycline levels found in sputum, including specific secretion of tetracyclines, inactivation by protein-binding, or degradation within the respiratory tract, but further facts are not available at present.

The minimum inhibitory concentrations of tetracycline strains for $\boldsymbol{H}$. influenzae reported previously have shown considerable variation. Franklin and Garrod (1953) found that only $41 \%$ of 22 strains tested were inhibited by 0.5 $\mu \mathrm{g} / \mathrm{ml}$ or less but all were sensitive to $1 \cdot 0 \mu \mathrm{g} / \mathrm{ml}$. Goslings, Valkenburg, and Los (1961) found that only $76 \%$ of 30 strains had an MIC of $1.0 \mu \mathrm{g} / \mathrm{ml}$. Hirsch and Finland (1960) and May and May (1963) both found a higher MIC; only $54 \%$ of the strains they tested were sensitive to $1 \cdot 6$ $\mu \mathrm{g} / \mathrm{ml}$ and $1.25 \mu \mathrm{g} / \mathrm{ml}$ respectively. In this study $86 \%$ had an MIC of $0.5 \mu \mathrm{g} / \mathrm{ml}$ or less and all but one of the strains were sensitive to 1.0 $\mu \mathrm{g} / \mathrm{ml}$. The Strep. pneumoniae strains were all sensitive to $0.5 \mu \mathrm{g} / \mathrm{ml}$ or less, an MIC which corresponds to that found by Rolinson and Stevens (19ó1). Kislak, Razavi, Daly, and Finland (1965), in a study of 200 recently isolated strains, found that $95 \%$ were sensitive to 0.4 $\mu \mathrm{g} / \mathrm{ml}$ and all but one to $0.8 \mu \mathrm{g} / \mathrm{ml}$.

$c$

In this study it has been shown that $86 \%$ of the $H$. influenzae strains tested, and all of the $\square$ Strep. pneumoniae, were sensitive to $0.5 \mu \mathrm{g} / \mathrm{ml} \stackrel{0}{F}$ tetracycline, which was the average level found으 in the sputum of patients receiving $1 \mathrm{~g}$ tetracycline $\Rightarrow$ daily by mouth. A sputum concentration of $1.0 \mu \mathrm{g} / \mathrm{ml}$ was outside the normal mean limits, 을 and thus organisms with this MIC or higher are probably not controllable by oral tetracycline $\frac{\bar{\rho}}{\vec{\rho}}$ therapy at this dosage. Thus it can be postulated $\stackrel{\Phi}{\propto}$ that if $\boldsymbol{H}$. influenzae is implicated in the morbidity of chronic respiratory disorders, about 80 to $90 \%$ of patients should benefit from the oral $\stackrel{\circ}{.}$ treatment with tetracycline $1 \mathrm{~g}$ daily. For the $\vec{\omega}$ remainder, or possibly all, to whom oral tetracycline therapy is given, a higher daily dosage융 should be employed. Conversely, by implication, $\mathrm{c}_{\mathrm{j}}$ it would appear that oral tetracycline therapyir in dosage less than $1 \mathrm{~g}$ daily is unlikely to be effective in a large proportion of respiratory tract infections with $H$. influenzae. These con-음 clusions appear to be borne out clinically bythe variable efficacy of tetracycline in chronic $\subseteq$ bronchitis, and by the ready elimination of $<$ Strep. pneumoniae, but only partial elimination $\overrightarrow{0}$ of $H$. influenzae in clinical trials of tetracycline $\triangle$ at various dosage regimes.

I should like to thank Professor R. E. O. Williams and Dr T. D. Brogan for helpful criticism at all $\varrho$ stages of this work, and also the consultant medical $\overrightarrow{\vec{O}}$ staff of St. Mary's Hospital, London, for permission 3 to study patients under their care. I am indebted to Dr W. D. Brighton for the production of the fluid medium used in the sensitivity testing of Strep. pneumoniae.

This study was made possible by a research grant from Glaxo Laboratories, and is to be submitted in? full as an M.D. thesis for the University of London.

References

Atassi, M. Z., Barker, S. A., and Stacey, M. (1962). Neuraminic N acid and its relation to chronic bronchitis. V. Glass column electrophoresis of sputum. Clin. chim. Acta, 7, 706-709.

Biserte, G., Havez, R., Voisin, C., Delahousse, P., Cuvelier, R., N and Gernez-Rieux, Ch. (1961). Lille med., 6, 51-61.

Brogan, T. D. (1960). The high molecular weight components of sputum. Brit. J. exp. Path., 41, 288-297.

Davis, A. L., Grobow, E. J., Tompsett, R., and McClement, J. H.O (1961). Bacterial infection and some effects of chemoprophylaxis in chronic pulmonary emphysema. I. Chemo-es prophylaxis with intermittent tetracycline. Amer. J. Med., 31, 365-381.

Eisner, H. J., and Wulf, R. J. (1963). The metabolic fate of chlortetracycline and some comparisons with other tetracyclines. J. Pharmacol. exp. Ther., 142, 122-131.

Fletcher, C. M. (1959). Chronic bronchitis: its prevalence, $\overrightarrow{\mathbb{D}}$ nature, and pathogenesis. Amer. Rev. resp. Dis., 80, 483-494.

Fletcher, C. M. (1965). Some recent advances in the prevention and treatment of chronic bronchitis and related disorders, $O$ with special reference to the effects of cigarette smoking Proc. roy. Soc. Med., 58,918-928.

Franklin, A. W., and Garrod, L. P. (1953). Chloramphenicolo treatment of bronchiectasis in children. Brit. med. J., 2 1067-1069. 
Gernez-Rieux, C., Biserte, G., Voisin, C., Havez, R., and Cuvelier, R. (1963). Etude biochimique de l'expectoration au cours de la bronchite chronique. J. franç. Med. Chir. thor., 17, 125-133.

Gibbons, R. A. (1959). Chemical properties of two mucoids from bovine cervical mucin. Biochem. J., 73, 209-217.

Gibbons, R. A. (1961). The biochemical and physical propertics of epithelial mucus. Amer. Rev. resp. Dis., 83, 568-569.

Gomori, G. (1946). Buffers in the range of $p H$ 6.5 to 9.6. Proc. Soc. exp. Biol. (N.Y.), 62, 33-34.

Goslings, W. R. O., Valkenburg, H. A., and Los, W. (1961). Antibiotic treatment of chronic infected bronchitis. In Bronchitis edited by N. G. M. Orie, and H. J. Sluiter, pp. 301-307. Van Gorcum, Assen and Thomas, Springfield, III.

Grove, D. C., and Randall, W. A. (1955). Assay Methods of Antibiotics: A Laboratory Manual, p. 50. Medical Encyclopedia Inc., New York.

Hafez, F. F., Stewart, S. M., and Burnet, M. E. (1965). Penicillin levels in sputum. Thorax, 20, 219-225.

Hers, J. F. P., and Mulder, J. (1953). The mucosal epithelium of the respiratory tract in muco-purulent bronchitis caused by Haemophilus influenzae. J. Path. Bact., 66, 103108.

Hirsch, H. A., and Finland, M. (1960). Susceptibility of Hemophilus influenzae to 21 antibiotics in vitro. Amer. J. med. Sci., 239, 33-40.

Holt, L. B. (1962). The growth-factor requirements of Haemophilus influenzae.J. gen. Microbiol., 27, 317-322.

Kislak, J. W., Razavi, L. M. B., Daly, A. K., and Finland, M. (1965). Susceptibility of pneumococci to nine antibiotics. Amer. J. med. Sci., 250, 261-268.

Kraus, F. W., Casey, D. W., and Johnson, V. (1951). Aureomycin and terramycin in human saliva. Proc. Soc. exp. Biol. (N.Y.), 78, 554-558.

Lighter, E. A., and Sobel, S. (1962). Variable sensitivity of assay methods of tetracycline and demethylchlortetracycline in human volunteers. Clin. Pharmacol. Ther., 3, 580-592.

McCormick, J. R. D., Fox, S. M., Smith, L. L., Bitler, B. A., Reichenthal, J., Origoni, V. E., Muller, W. H., Winterbottom, R., and Doerschuk, A. P. (1957). Studies of the reversible epimenization occurring in the tetracyline family: the preparation, properties and proof of structure of some 4-epi-tetracyclines. J. Amer. chem. Soc., 79, 2849-2858.

May, J. R. (1953). The bacteriology of chronic bronchitis. Lancet, 2, 534-537.
May, J. R. (1955). The laboratory background to the use of penicillin in chronic bronchitis and bronchiectasis. Brit.? J. tuberc., 49, 166-173.

May, J. R., and May, D. S. (1963). Bacteriology of sputum in chronic bronchitis. Tubercle (Edinb.), 44, 162-173.

May, J. R., and Delves, D. M. (1964). Ampicillin in the treatmen of Haemophilus influenzae infections of the respiratory tract. Thorax, 19, 298-305.

May, J. R., and Delves, D. M. (1965). Treatment of chronio bronchitis with ampicillin: some pharmacological ob? servations. Lancet, 1,929-933.

May, J. R. (1964). Ampicillin in the therapy of chronic bronchitis Postgrad. med.J., 40,Suppl., 193.

Maynard, A. de L., Andriola, J. C., and Prigot, A. (1953-54) Tetracycline hydrochloride studies on absorption, diffusion $\mathbb{D}$ excretion, and clinical trial. Antibiot. Ann., 102-107.

Mulder, J. (1938). Haemophilus influenzae (Pfeiffer) as an ubiqui tous cause of common acute and chronic purulent bronchitis. Acta med. scand., 94,98-140.

Mulder, J., Goslings, W. R. O., van der Plas, M. C., and Lopes Cardozo, P. (1952). Studies on the treatment with antibacterial drugs of acute and chronic mucopurulenf bronchitis caused by Haemophilus influenzae. Acta med scand., 143, 32-49.

Nomoto, M., and Narahashi, Y. (1959). A proteolytic enzyme of Streptomyces griseus. J. Biochem. (Tokyo), 46, 653, 839 1481 , and 1645 .

Putnam, L. E., Hendricks, F. D., and Welch, H. (1953). Tetra or cycline, a new antibiotic. Antibiot. Chemother.; 3, 1183+u 1186.

Rawlins, G. A. (1953). Liquefaction of sputum for bacteriologicaP examination. Lancet, 2, 538-539.

Reid, L. M. (1954). Pathology of chronic bronchitis. Lancet 1,275-278.

Rolinson, G. N., and Stevens, S. (1961). Microbiological studie on a new broad-spectrum penicillin, 'Penbritin'. Brit med.J., 2, 191-196.

Saggers, B. A., and Lawson, D. (1968). In vivo penetration of antibiotics into sputum in cystic fibrosis. Arch. Dis. Childh., 43, 404-409.

Schach von Wittenau, M. , and Yeary, R. (1963). The excretion and distribution in body fluids of tetracyclines after intravenous administration to dogs. J. Pharmacol, exp Ther., 140, 258-266.

Wozniak, L. A. (1960). Studies on binding of tetracyclines b? dog and human plasma. Proc. Soc. exp. Biol. (N.Y.)@ $105,430-433$.

\section{Reports and Bulletins prepared by the Association of Clinical Biochemists}

The following reports and bulletins are published by the Association of Clinical Biochemists. They may be obtained from The Administrative Office, Association of Clinical Biochemists, 7 Warwick Court, Holborn, London, W.C.1. The prices include postage, but airmail will be charged extra. Overseas readers should remit by British Postal or Money Order. If this is not possible the equivalent of 10s. is the minimum amount that can be accepted.

\section{SCIENTIFIC REPORTS}

3 Automatic Dispensing Pipettes. An assessment of 35 commercial instruments 1967 P. M. G. BROUGHTON, A. H. GOWENLOCK, G. M. WIDDOWSON, and $\mathrm{K}$. A. AHLQUIST 17s (\$2)

\section{An Evaluation of 5 Commercial} Flame Photometers suitable for the Simultaneous Determination of Sodium and Potassium March 1970 P. M. G. BROUGHTON and J. B. DAWSON 17s (\$2)

\section{TECHNICAL BULLETINS}

9 Determination of Urea by AutoAnalyzer November 1966 RUTH M. HASLAM 8s 6d (\$1)

10 Filter Fluorimeters. A comparative list of 14 instruments March 1967 HANNELORE BRAUNSBERG (Re-issued in response to demand. Text still valuable, list now out of date) $8 \mathrm{~s} 6 \mathrm{~d}(\$ 1)$
11 Determination of Serum Albumin by AutoAnalyzer using Bromocresol Green October 1967 B. E. NORTHAM and G. M. WIDDOwson 8s 6d (\$1)

13 An Assessment of the Technicon Type II Sampler Unit March 1968 B. C. GRAY and G. K. MCGOWAN 8s 6d $(\$ 1)$

14 Atomic Absorption Spectroscopy. An outline of its principles and a guide to the selection of instruments May 1968 J. B. DAWSON and P. M. G. BROUGHTON 8s 6d (\$1)

15 A Guide to Automatic Pipettes (2nd edition) June 1968 P. M. G. BROUGHTON 8s 6d (\$1)

16 A Guide to Automation in Clinical Chemistry May 1969 P. M. G. BROUGHTON 12s 6d (\$1.50)
17 Flame Photometers (2nd edition) 1969 P. WILDING 12s 6d (\$1.50)

18 Control Solutions for Clinical Biochemistry (4th edition) March 1970 P. M. G. BROUGHTON $12 \mathrm{~s} 6 \mathrm{~d}$ (\$1.50)

19 Spectrophotometers. A comparative list of low-priced instruments readily available in Britain May 1970 C. E. WILDE and P. SEWELL $12 \mathrm{~s} 6 \mathrm{~d}(\$ 1.50)$

v

